\title{
Expression Patterns of Galectin-1 and Galectin-3 in Hibernating Anatolian Ground Squirrel (Spermophilus Xanthoprymnus) Gastrointestinal Tract
}

\author{
Mehmet ÖZBEK ${ }^{1 *}$, Mustafa ÖZTOP² \\ ${ }^{1}$ Burdur Mehmet Akif Ersoy University, Faculty of Veterinary Medicine, Department of Histology and Embryology, 15030, \\ Burdur, Turkey \\ ${ }^{2}$ Burdur Mehmet Akif Ersoy University, Faculty of Science and Art, Department of Biology, 15030, Burdur, Turkey
}

\begin{abstract}
Hibernation is a survival adaptation characterized by extended fasting when food is less or unavailable. Prolonged fast may affects various proteins expression including galectins binding $\beta$-galactosyl. There is no data on the expression of Galectin-1 and -3 (Gal-1 and -3) during hibernation. This study aimed to examine the expression of Gal-1 and -3 in hibernating Anatolian ground squirrel (Spermophilus xanthoprymnus) gastrointestinal tract. Intense Gal-1 immunostaining was observed in some cells of both gastric lamina propria and villous connective tissue of the small intestine. In colon and cecum, intense Gal-1 immunoreaction was observed in some connective tissue cells around the crypt epithelium, as well as in the smooth muscles of vessel walls, lamina muscularis and tunica muscularis of all the regions. Gastric foveolar epithelium showed moderate nuclear and intracytoplasmic Gal-3 immunostaining. Moreover, Gal-3 immunostaining was detected in villous epithelial cells of the duodenum and ileum. Intense Gal-3 labeling also was present in all the cryptal surface epithelial cells of the colon and cecum. In conclusion, both Gal-1and Gal-3 expression in gastrointestinal tract during hibernation was similar to that of non-hibernating species. In the gastrointestinal tract, Gal-1 did not display different expression pattern, whereas Gal-3 expression was more intense in large intestine epithelium.
\end{abstract}

Keywords: Anatolian ground squirrel, Galectin, Hibernation, Spermophilus xanthoprymnus

\section{Hibernasyondaki Anadolu Yer Sincabı (Spermophilus xanthoprymnus) Gastrointestinal Kanalında Galektin-1 ve Galektin-3'ün Ekspresyon Paternleri}

\section{ÖZ}

Hibernasyon, besinin az olduğu veya hiç olmadığı uzun süreli açlık ile karakterize olan durumlarda hayatta kalma adaptasyonudur. Uzun süreli açlık $\beta$-galaktozil bağlayan galektinler de dahil olmak üzere bir çok proteinin ekspresyonunu etkileyebilir. Galektinler, $\beta$-galaktozil bağlayan proteinlerdir. Hibernasyonda Galektin-1 ve -3 (Gal1 ve-3)'ün ekspresyonuna ilişkin herhangi bir veri bulunmamaktadır. Bu çalışmada hibernasyondaki Anadolu yer sincab1 (Spermophilus xanthoprymnus) gastrointestinal kanalında Gal-1 ve 3'ün ekspresyonunun incelenmesi amaçlanmıştır. Hem gastrik lamina propria hem de ince bağırsağın villöz bağ dokusundaki bazı hücrelerde yoğun Gal-1 immün boyanması gözlendi. Gastrointestinal kanalın bütün bölümlerindeki damar duvarları, lamina muskularis ve tunika muskularisindeki düz kaslarda yoğun Gal-1 ekspresyonu gözlendi. Ayrıca kolon ve sekumda kript epiteli etrafindaki bazı bağ dokusu hücrelerinde de yoğun Gal-1 immünoreaksiyonu belirlendi. Gastrik foveoler epitel hücreleri orta derecede nükleer ve intrasitoplazmik Gal-3 immun reaksiyon gösterdi. Duodenum ve ileumun villöz epitel hücrelerinde Gal-3 immün boyaması tespit edildi. Ayrıca, kolon ve sekumdaki kriptlerin yüzey epitel hücrelerinde yoğun Gal-3 boyanması görüldü. Sonuç olarak hibernasyon sürecinde gastrointestinal kanaldaki hem Gal-1 hem de Gal-3 ekspresyonu hibernasyona yatmayan türlerle benzerdi. Gastrointestinal kanal bölümlerinde Gal-1 ekspresyonu açısından farkll1ık gözlenmezken, Gal-3 ekspresyonu diğer gastrointestinal bölümlere nazaran kalın bağısak epitelinde daha yoğundu.

Anahtar Kelimeler: Anadolu yer sincab1, Galektin, Hibernasyon, Spermophilus xanthoprymnus

To cite this article: Özbek M. Öztop M. Expression Patterns of Galectin-1 and Galectin-3 in Hibernating Anatolian Ground Squirrel (Spermophilus Xanthoprymnus) Gastrointestinal Tract. Kocatepe Vet J. (2020) 13(1):77-85. 


\section{INTRODUCTION}

Galectins, also known as soluble-type lectins, are a family of proteins and bind $\beta$-galactosyl-containing glycoconjugates with a high affinity. Fifteen galectins have been discovered in mammals until now and all of them possess a common carbohydrate recognition domain (CRD) (Nio-Kobayash 2017). From the point of view of protein structure, some galectins (Galectin 1 and 2 termed as a prototype) include only one CRD and are found as dimers while other galectins (Galectin 4, 8, and 9) harbor two non-identical CRDs linked with a short linking region (tandem repeat type). Galectin-3 (the chimera type) is distinctive as it is found as a monomer and consists of only one Cterminal CRD co-existed with an N-terminal regulatory domain (Houzelstein et al. 2004). Most of galectins are produced by various cell types and are found in both intracellular and extracellular locations. Intracellular galectins might affect various biological processes and cellular signaling through proteinprotein interactions in a way that is independent of their glycan-binding activity (Liu et al. 2002) while extracellular galectins control the activity of cytokines by having an effect on their levels of expression and secretion and by impeding the diffusion of cytokines through the extracellular matrix (Gordon-Alonso et al. 2018). Though binding either bivalently or multivalently to glycoconjugates on cell surfaces and cross-linking with them, galectins could regulate cellular processes such as cytokine secretion, apoptosis, migration and adhesion (Rubinstein et al. 2004). In this respect, galectins have been involved in various cellular functions, including differentiation, activation, regulation and survival of $\mathrm{T}$ cells and, therefore, may have key roles in the regulation of chronic inflammatory disorders like inflammatory bowel diseases (IBD) and other autoimmune diseases (Müller et al. 2006). The digestive system of mammals contains a lot of galectins (Nio et al. 2005). Gal-1 and -3 are the most examined members of the galectin family. Surprisingly, Gal-1 is widely expressed in different portions of the mouse and human gastrointestinal system and is involved in some intestinal disorders such as IBD and colorectal cancer (Santucci et al. 2003, Mizoguchi and Mizoguchi 2007, Hokama et al. 2008, Ose et al. 2012). On the other hand, Gal-3 is highly produced by subepithelial macrophages and enterocytes in the gastrointestinal tract (Lotz et al. 1993, Brazowski et al. 2009). Gal-3 is predominately found in giant inclusions at the apical membrane of confluent enterocytes. Gal-3 has been reported to be secreted from a variety of cell types through a nonclassical secretory pathway (Cooper and Barondes 1990, Huflejt et al. 1997, Puthenedam et al. 2011).

Hibernators, including the Anatolian ground squirrels examined here, provide the unique opportunity to investigate what is naturally organ preservation.
Torpor bouts, which are characterized by minimal body temperature and suppressed metabolism $(2-4 \%$ of euthermic levels), greatly resemble cold periods (2$4^{\circ} \mathrm{C}$ ) used for organ preservation (Green 2000). Although hibernating animals become well acclimatized to harsh winter conditions and tend to rely heavily on these radical changes for survival each year, hibernation could be considered to be stressful to the gastrointestinal tract from various aspects including prolonged hypothermia, extended fasting, redistribution of blood flow and rapid changes in metabolism (Carey et al. 2001). The gastrointestinal immune system exhibits some alterations during hibernation. Indeed, long torpor phase makes gut epithelium leakier, which in turn leads to the passage of many molecules and bacteria in an uncontrolled manner (Kurtz and Carey 2007). The increased permeability may give rise to a hyperactivation of the immune system in hibernating mammals. Although gastrointestinal tract stunningly harbors a higher number of immune cells during hibernation, the mucosal structure seems to escape unscathed from the torpor bouts and there exist no observable signs of pathology (Kurtz and Carey 2007, Sisa et al. 2017). Many studies exist on Gal-1 and -3 expression in gastrointestinal tract of non-hibernating animals (NioKobayash 2017). However, there is a lack of knowledge in their expression in gastrointestinal tract during hibernation. Knowledge of how hibernation influences Gal-1 and 3 expression in the gastrointestinal tract being exposed to various stressful factors might shed new light on gastrointestinal physiology and contribute to success rates of intestinal surgery, including transplantation. For this purpose, we aimed to investigate Gal-1 and 3 expression in hibernating Anatolian ground squirrel (Spermophilus xanthoprymnus) gastrointestinal tract.

\section{MATERIAL and METHODS}

\section{Experimental Design and Ethical Declaration}

Animal experiments were conducted in accordance with the guidelines on Animal Care and Use after approval (\#15/140) by Local Ethics Committee for Animal Experiments of Erciyes University (HADYEK). Six male Anatolian ground squirrels (Spermophilus xanthoprymnus) were included in the study. Animals' weights were within the range of 300 to $380 \mathrm{~g}$. Squirrels were wild captured from steppes with the help of Tomahawk Traps (Model \#202) in Develi (Kayseri, Turkey) in August 2016. Thus, their absolute ages are unknown. Squirrels were then transported to the laboratory where they were put in quarantine for about one week in cages with a steady laboratory temperature of $21^{\circ} \mathrm{C}$ under $12: 12 \mathrm{~h}$ lightdark cycle conditions until ensuring they had very healthy. Squirrels that would enter hibernation were fed on fresh fruit, sunflower seeds, standard rodent mix and water ad libitum until they saved enough quantities of fat before hibernation. Initially, the 
ambient temperature was adjusted to $21 \pm 1^{\circ} \mathrm{C}$ and the artificial photoperiodic conditions (light-dark cycle, 200-0 lux) was adjusted to imitate the external photoperiod. Environment temperature was fallen to $6^{\circ} \mathrm{C}$ from September 2016 to December 2016. The food substances were taken away from the cages. Lights were turned out to make the transition into torpor easier. When going into the laboratory, a red safe light (3-5 lux) was shut on in order not to frighten torpid squirrels. Three months later, squirrels were anesthetized with intraperitoneal ketamine (88.9 $\mathrm{mg} / \mathrm{ml})$ and xylazine $(11.1 \mathrm{mg} / \mathrm{ml})$ and euthanized with cardiac puncture (Olson and McCabe 1986). After that, stomach and intestine parts were quickly removed from each animal and dissected. The stomach and intestine samples were fixed in $10 \%$ formol-alcohol solution. After histological fixation, the samples were dehydrated in ascending series of ethanol. The tissue samples were then passed through a series of methyl benzoate and benzol. After clearing, the samples were embedded in paraplast for permanent tissue blocks.

\section{Immunohistochemical Analysis}

Sections (5 $\mu \mathrm{m}$ in thickness) were obtained from stomach and intestine blocks by employing a rotary microtome (Leica RM2125RT) and collected on poly1-lysine coated slides. The Labeled StreptavidinBiotin (LSAB) staining method was performed for immunohistochemical analysis as previously described (Özbek et al. 2018). Slides were deparaffinized with xylene and rehydrated by passing through alcohol series (from 100\%, 96\%, 80\% to $70 \%$ ). Upon washing with phosphate-buffered saline (PBS), antigen retrieval was performed by heating sections in a citrate buffer $(0.01 \mathrm{M}, \mathrm{pH}$ 6.0) within a microwave oven at full power for $20 \mathrm{~min}$ to unmask antigenic epitopes. Then, slides were cooled down at room temperature for $20 \mathrm{~min}$, following washing in PBS containing $0,2 \%$ Triton $\mathrm{X}-100$ to enhance the membrane permeability. Then, endogenous peroxidase activity was inhibited by incubating in 3\% hydrogen peroxide $\left(\mathrm{H}_{2} \mathrm{O}_{2}\right)$ in distilled water in a dark humidity chamber. Sections were then rinsed for 15 min in PBS and encircled by a liquid blocker. Nonspecific binding was blocked using Ultra V Block. After removed more solution from the sections, slides were treated with anti-Galectin- 1 and -3 primary antibodies listed in Table 1 overnight at $4^{\circ} \mathrm{C}$. The next day, procedures were resumed. 3-amino-9ethylcarbazole (AEC, \#TA-125-HA) was added onto slides to demonstrate the resultant signal. The slides were counterstained with Gill's hematoxylin and mounted in a water-based mounting medium (\# TA060-UG). All dilutions were determined according to manufacturer's instructions. The immunohistochemical staining specificity was confirmed through negative and positive controls. Both normal rabbit IgG (non-immune sera, \#sc2027) and PBS were replaced with the primary antibodies for negative controls. Squirrel testes and epididymis were employed for positive control. Immunohistochemical procedure was repeated three times for each sample to confirm staining reliability.

Semi-quantitative assessment of immunostaining Immunoreactive sections were assessed using BX51 microscope (Olympus). Photographs were then taken with the help of a digital camera (DP74). We used three sections cut at $50 \mu \mathrm{m}$ interval for each animal. Four randomly selected areas were examined per section. Immunostaining was evaluated semiquantitatively using an intensity score (IS). The IS of the immunostaining reactivities in the cells was determined independently by the authors. The staining intensity of Gal-1 and Gal-3 in the gastrointestinal tract was examined microscopically at 40, 100, 200 and 400 magnification. Results of IS were presented as 0 (no staining), + (weak staining), ++ (moderate staining) and +++ (intense staining) as previously described (Öztop et al. 2019). Semiquantitative scoring is summarized in Table 2.

\section{RESULTS}

\section{Galectin-1 Staining}

We examined all three parts of the stomach, including cardia, fundus and pylorus. In the all three parts, some cells in the lamina propria show intense immunoreaction. We also observed intense labelling in smooth muscle cells of vessel walls, lamina muscularis, and tunica muscularis. In the small intestine, intense immunostaining was detected in some cells of the villous connective tissue while few cells were positive for Gal-1 in submucosa. In the colon and cecum, intense immunoreaction was also observed in some connective tissue cells around crypts epithelium. As in stomach, we detected an intense immunostaining in smooth muscles of vessel walls, lamina muscularis and tunica muscularis (Fig. 1 and 2).

\section{Galectin-3 Staining}

Gastric foveolar epithelium showed moderate nuclear and intracytoplasmic immunostaining in all three parts of the stomach, including cardia, fundus and pylorus. In the duodenum and ileum, we observed immunostaining in villous epithelial cells but not in crypt epithelium. Interestingly, some cells in the intestinal villi were not positive for Gal-3. In the colon and cecum, we detected an intense labelling in all surface cells of crypt epithelium but not in cells at bottom of crypts (Fig. 3 and 4). 

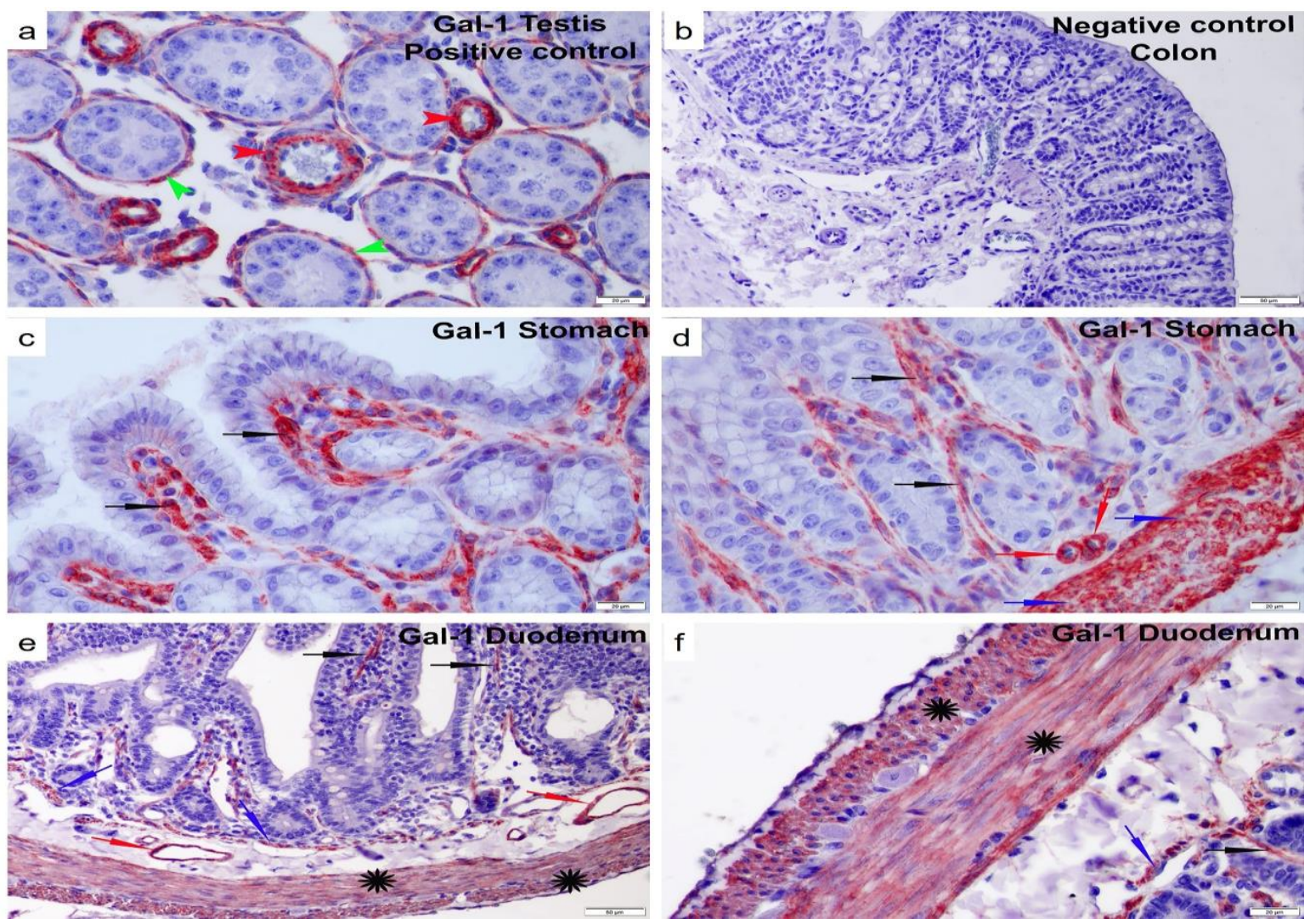

Figure 1. Representative images showing positive control (a), negative control (b) and Gal-1 expression in hibernating Anatolian ground squirrel (Spermopbilus xanthoprymmus) stomach (c, d) and duodenum (e, f). Peritubular myoid cells (green arrowheads) and vessel walls (red arrowheads) showed positive immunostaining in control testis. In stomach and duodenum, intense immunostaining was observed in smooth muscles of vessel walls (red arrows), lamina muscularis (blue arrows), and tunica muscularis (black asterisk). Some cells of lamina propria (black arrows) also were intensely positive for Gal-1. Bars: $50 \mu \mathrm{m}(\mathrm{b}, \mathrm{e})$ and $20 \mu \mathrm{m}(\mathrm{a}, \mathrm{c}, \mathrm{d}, \mathrm{f})$.
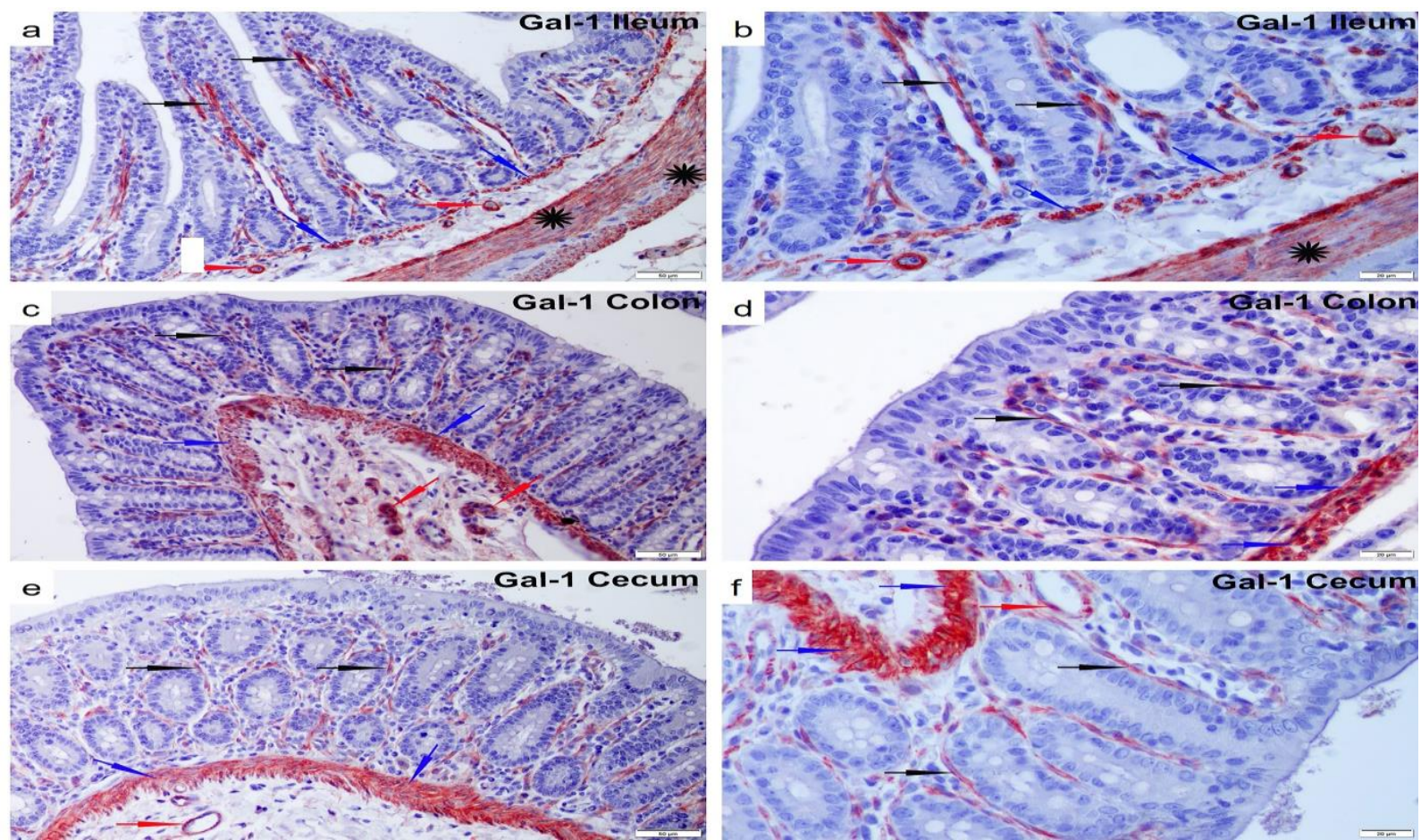

Figure 2. Representative images showing Gal-1 expression in hibernating Anatolian ground squirrel (Spermophilus xanthoprymnus) ileum (a, b), colon (c, d) and cecum (e, f). Intense immunostaining was observed in smooth muscles of vessel walls (red arrows), lamina muscularis (blue arrows), and tunica muscularis (black asterisk). Intense immunostaining in some cells (black arrows) of lamina propria. Bars: $50 \mu \mathrm{m}(\mathrm{a}, \mathrm{c}, \mathrm{e})$ and $20 \mu \mathrm{m}(\mathrm{b}, \mathrm{d}, \mathrm{f})$. 

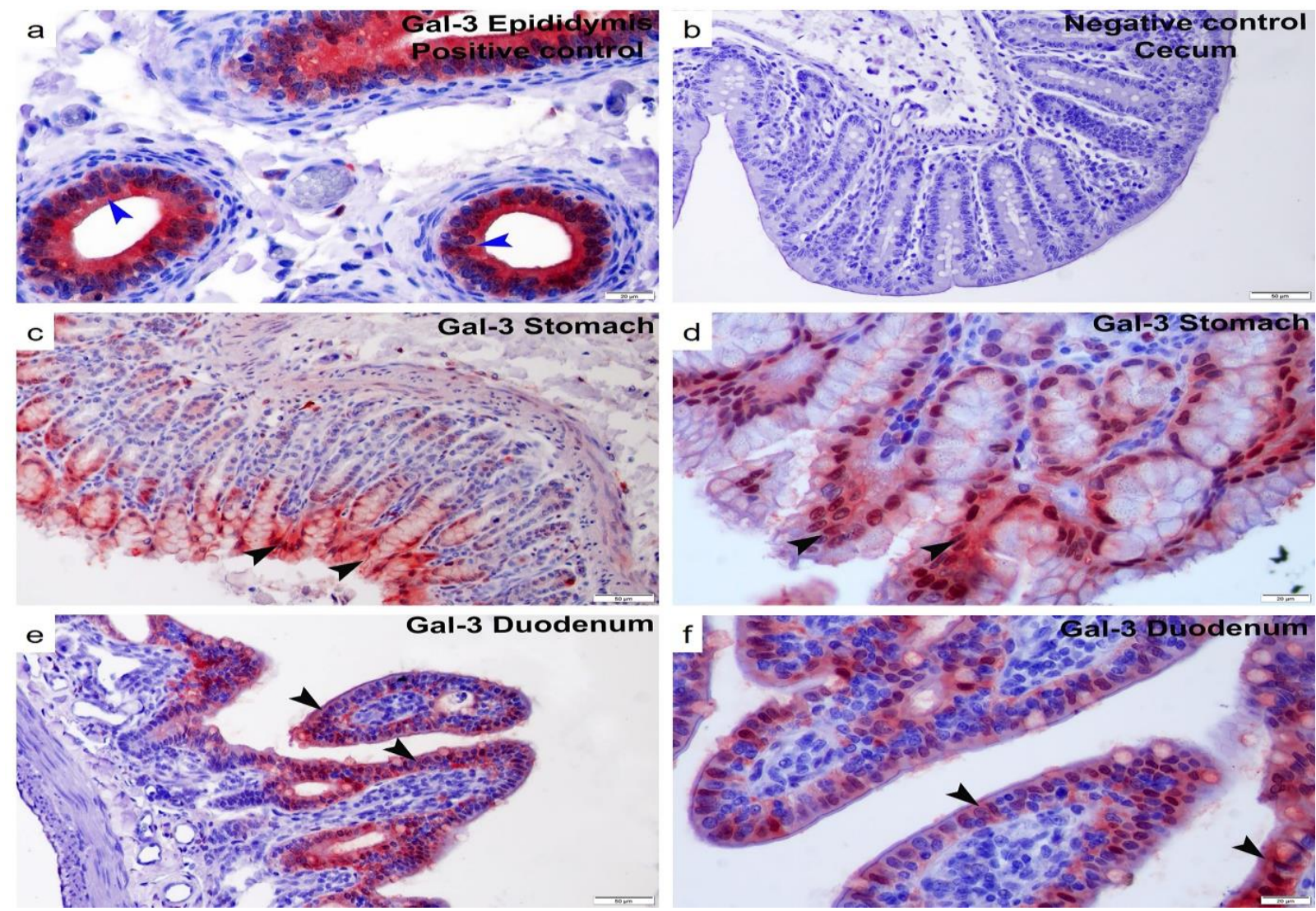

Figure 3. Representative images showing positive control (a), negative control (b) and Gal-3 expression in hibernating Anatolian ground squirrel (Spermophilus xanthoprymnus) stomach (c, d) and duodenum (e, f). Epididymal epithelium (blue arrowheads) showed positive immunoreaction in control epididymis. In stomach, moderate nuclear and intracytoplasmic staining were observed in foveolar epithelium (black arrowheads). Some cells of villous epithelium (black arrowheads) were positive for Gal-3in duodenum. Bars: $50 \mu \mathrm{m}(\mathrm{b}, \mathrm{c}, \mathrm{e})$ and $20 \mu \mathrm{m}(\mathrm{a}, \mathrm{d}, \mathrm{f})$.
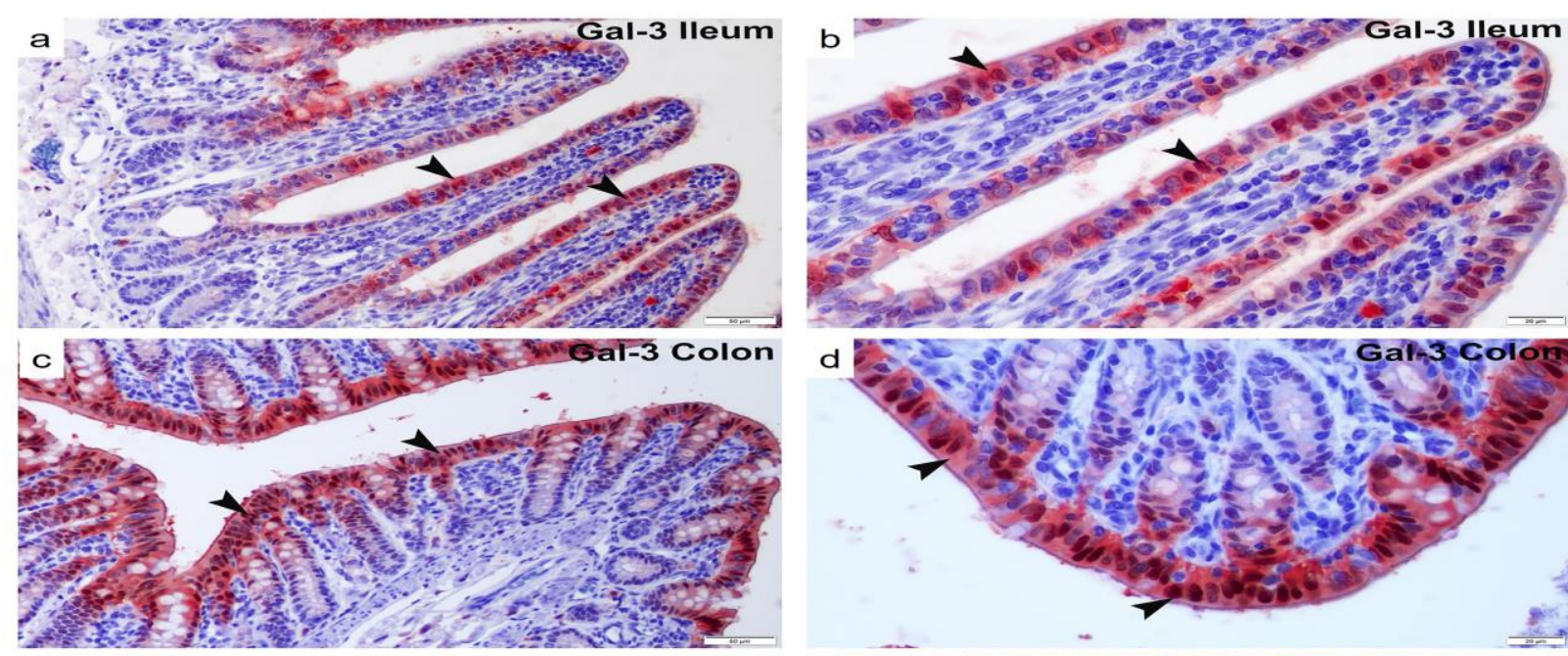

e

Gal-3 Cecum
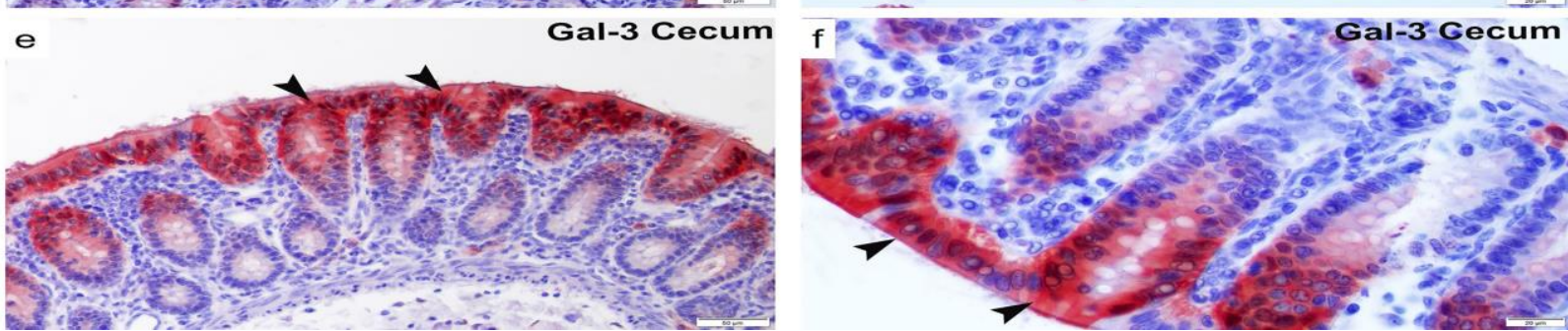

Figure 4. Representative images showing Gal-3 expression in hibernating Anatolian ground squirrel

(Spermophilus xanthoprymnus) ileum (a, b), colon (c, d) and cecum (e, f). Some cells of villous epithelium (black arrowheads) showed moderate positive immunostaining in ileum. In colon and cecum, intense immunostaining was observed in surface cells (black arrowheads) of crypt epithelium. Bars: $50 \mu \mathrm{m}$ (a, c, e) and $20 \mu \mathrm{m}(\mathrm{b}, \mathrm{d}, \mathrm{f})$. 
Table 1. Primary antibodies used for immunohistochemistry (IHC).

\begin{tabular}{|c|c|c|c|c|c|c|}
\hline Antibody & Clonality & Immunogen & Host & Dilution & $\begin{array}{l}\text { Catalogue } \\
\text { no* }\end{array}$ & Reactivity \\
\hline Gal-1 & Polyclonal & $\begin{array}{l}\text { Recombinant human galectin } 1 \\
\text { consisting of } 110 \text { amino acids }\end{array}$ & Rabbit & $1 / 250$ & $\begin{array}{l}\text { NBP1- } \\
89791\end{array}$ & $\begin{array}{l}\text { Human, } \\
\text { mouse, rat }\end{array}$ \\
\hline Gal-3 & $\begin{array}{l}\text { Monoclonal } \\
\text { Clone } \\
\text { A3A12 }\end{array}$ & $\begin{array}{l}\text { Full length recombinant human } \\
\text { galectin } 3\end{array}$ & Mouse & $1 / 300$ & $\begin{array}{l}\text { NB300- } \\
538\end{array}$ & $\begin{array}{l}\text { Human, } \\
\text { mouse, rat, } \\
\text { rabbit }\end{array}$ \\
\hline
\end{tabular}

*All antibodies listed were provided from Novus Biologicals.

Table 2. Semiquantative evaluation of Galecin-1 and -3 staining in hibernating Anatolian ground squirrel (Spermophilus xanthoprymnus) gastrointestinal tract.

\begin{tabular}{|c|c|c|c|}
\hline Tissue & Region & Galectin-1 & Galectin-3 \\
\hline \multirow{5}{*}{ Stomach } & Foveolar epithelium & - & $++/ \mathrm{n}, \mathrm{ic}$ \\
\hline & Some cells in lamina propria & $+++/$ ic & - \\
\hline & Smooth muscles of lamina muscularis & $+++/$ ic & - \\
\hline & Smooth muscles of tunica muscularis & $+++/$ ic & - \\
\hline & Vessel walls & $+++/$ ic & - \\
\hline \multirow{5}{*}{ Duodenum } & Villous epithelium & - & $++/ \mathrm{n}, \mathrm{ic}$ \\
\hline & Some cells in lamina propria & $+++/$ ic & - \\
\hline & Smooth muscles of lamina muscularis & $+++/$ ic & - \\
\hline & Smooth muscles of tunica muscularis & $+++/$ ic & - \\
\hline & Vessel walls & $+++/$ ic & - \\
\hline \multirow{5}{*}{ Ileum } & Villous epithelium & - & $++/ \mathrm{n}, \mathrm{ic}$ \\
\hline & Some cells in lamina propria & $+++/$ ic & - \\
\hline & Smooth muscles of lamina muscularis & $+++/$ ic & - \\
\hline & Smooth muscles of tunica muscularis & $+++/$ ic & - \\
\hline & Vessel walls & $+++/$ ic & - \\
\hline \multirow{5}{*}{ Colon } & Villous epithelium & - & $+++/ \mathrm{n}, \mathrm{ic}$ \\
\hline & Some cells in lamina propria & $+++/$ ic & - \\
\hline & Smooth muscles of lamina muscularis & $+++/$ ic & - \\
\hline & Smooth muscles tunica muscularis & $+++/$ ic & - \\
\hline & Vessel walls & $+++/$ ic & - \\
\hline \multirow{5}{*}{ Cecum } & Villous epithelium & - & $+++/ \mathrm{n}, \mathrm{ic}$ \\
\hline & Some cells in lamina propria & $+++/$ ic & - \\
\hline & Smooth muscles of lamina muscularis & $+++/$ ic & - \\
\hline & Smooth muscles of tunica muscularis & $+++/$ ic & - \\
\hline & Vessel walls & $+++/$ ic & - \\
\hline
\end{tabular}

The degree of immunostaining was determined as either negative $(-)$, weak $(+)$, moderate $(++)$ or intense $(+++)$ by two independent observers (MÖ, MÖ), as previously described (Öztop et al., 2019). n: nuclear staining, ic: intracytoplasmic staining.

\section{DISCUSSION}

Here, we report an immunohistochemical analysis of Gal-1 and -3 expression in hibernating Anatolian ground squirrel (Spermophilus xanthoprymnus) gastrointestinal tract. The present study clearly showed that Gal-1 and -3 were expressed in all gastrointestinal tract during hibernation.

It has been showed that Gal-1 expression was at low levels in many tissues, but abundant particularly in cardiac, skeletal and smooth muscle cells (Catt et al. 1987, Wasano et al. 1990, Barondes et al. 1994). In addition, Gal-1 is constitutively expressed in vascular smooth muscle cells (VSMCs) and has been regarded as a constituent of the vascular extracellular matrix (Barondes 1984, Moiseeva et al. 1999). Previous studies have indicated that recombinant Gal-1 protein improved VSMC proliferation and regulated the spreading, migration and attachment of VSMCs (Moiseeva et al. 1999, Moiseeva et al. 2000). Gal-1 also regulates vascular constriction through controlling the surface expression of Cav1.2 channel in VSMCS (Wang et al. 2011). Furthermore, Gal-1 deficiency affects remodeling and vasocontractile response in hypoxia-induced pulmonary hypertension 
in animals (Case et al. 2007). In the present study, we observed Gal-1 expression in smooth muscle cells of lamina muscularis, tunica muscularis and vessel walls in the gastrointestinal tract as in non-hibernating animals. Considering previous studies, we suggest that Gal-1 plays a key role in the maintenance of vascular homeostasis in hibernation as in non-hibernating period. However, we could not spot any difference in Gal-1 expression in smooth muscle cells in all the examined regions using the immunohistochemical analysis. Quantitative analysis should be used to determine the effect of hibernation on Gal-1 expression in smooth muscle cells in the gastrointestinal tract.

Gal-1 also has a role in immune responses of gastrointestinal tract to microbial infection, especially regarding macrophage and $\mathrm{T}$ cell responses as well, but can be made up for to maintain normal colonization and infection resolution. Gal-1 binds to N-glycans of proteins CD7, CD43 and CD45 on the surface of activated $\mathrm{T}$ cells. This results in segregation of these proteins into membrane microdomains and triggering of apoptosis (Barondes et al. 1994, Camby et al. 2006). The deficiency in Gal-1 led to a decrease in the $\mathrm{T}$ cell influx into the lamina propria as infection had occurred. Furthermore, mice deficient in Gal-1 had a limited number of macrophages in the lamina propria before developing infection and failed to evoke a macrophage response to infection at the time point being considered at least (Curciarello et al. 2014). Kaltner et al. (2002) detected Gal-1 expression in fibroblast in lamina propria of bovine duodenum and colon but not in epithelial cells. However, some researcher observed Gal-1 expression in colonic epithelial cells (Santucci et al. 2003). In our study, Gal-1 expression was found in some cells of lamina propria as in non-hibernating animals. These cells may be fibroblast, based on previous study (Kaltner et al. 2002). Gal-1 positive cells in lamina propria may be involved in mucosal immune system homeostasis during hibernation as in non-hibernating animals. We think that the differences among studies (Santucci et al. 2003) may be due to methodological error or use of poor-quality primary antibody.

Gal-3 suppresses apoptosis in vitro via a cell death inhibition pathway involving Bcl-2 (Yang et al. 1996). Reports on mice indicated that mouse duodenal and colonic epithelium exhibited a nuclear and intracytoplasmic Gal-3 expression (Brassart et al. 1992). Furthermore, other researchers reported Gal-3 expression in stomach, ileum and colon epithelium (Demetter et al. 2008) and in bovine duodenum and colon epithelium (Kaltner et al. 2002). Gal-3 has also been detected in various types of tumor cells both in vivo (Woo et al. 2001, Takenaka et al. 2003) and in vitro (Cebo et al. 2002). In addition, Gal-3 mRNA was detected by an intensified expression on the luminal side of the intestinal and gastric mucosa in mice (Sanjuán et al. 1997). Moreover, another researcher reported that Gal-3 mainly localized at the myosin-rich terminal web of fully matured epithelial cells at the villus intestinalis tips. In addition, the apical localization of Gal-3 also was detected in T84 cells and polarizing epithelial cell lines (Lindstedt et al. 1993, Huflejt et al. 1997). Delacour et al. (2006) showed that intracellular sorting and correct targeting of glycoproteins to the apical plasma membrane were dependent on Gal-3. This has been supported with the finding that, in Gal-3 knockout mice, villin and actin abundant in the brush border become abnormally spread over baso-lateral membranes (Delacour et al. 2008). Moreover, interaction of Gal-3 with cytokeratins (Goletz et al. 1997), actin (Joubert et al. 1992), and possibly tubulin (Ozaki et al. 2004) has been described. Consistent with non-hibernating animals, we detected a nuclear and intracytoplasmic Gal-3 expression in epithelial cells at top of foveola gastrica, intestinal villi and the top of large intestine crypt. Gastric and small intestinal epithelium showed moderate immunoreaction while large intestinal epithelium demonstrated intense immunostaining. This may be due to actin, myosin or intermediate filament contents of epithelial cells, as described in previous study. Interestingly, some cells in the intestinal villi were not positive for Gal-3. These cells may undergo apoptosis during hibernation. In addition, we also suggest that Gal-3 may act to prevent luminal epithelial cells of the gastrointestinal mucosa from cell death.

In conclusion, this is the first study that describes Gal-1 and -3 expression in the gastrointestinal tract of hibernating Anatolian ground squirrel (Spermophilus xanthoprymnus). While Gal-1 expression was detected in smooth muscle cells and some cells of lamina propria, Gal-3 expression was determined in luminal cells of gastrointestinal mucosa. Both Gal-1and Gal-3 expression in gastrointestinal tract was similar to that of other species using immunohistochemical analysis. Gal-1 expression was not different in the gastrointestinal tract, whereas Gal-3 expression was more intense in the large intestine epithelium. Further studies are required to investigate possible roles of galectins during hibernation.

\section{ACKNOWLEDGEMENT}

\section{> Local Ethics Committee for Animal Experiments of Erciyes University (15/140)}

Conflict of Interest: The authors declare that they have no conflict of interest.

\section{REFERENCES}

Barondes SH, Castronovo V, Cooper DN, Cummings RD, Drickamer K, Feizi T, Gitt MA, Hirabayashi J, Hughes C, Kasai K, et al. Galectins: a family of animal 
beta-galactoside-binding lectins. Cell. 1994; 76(4): $597-$ 598.

Barondes SH. Soluble lectins: a new class of extracellular proteins. Science. 1984; 223(4642): 1259-1264.

Brassart D, Kolodziejczyk E, Granato D, Woltz A, Pavillard M, Perotti F, Frigeri LG, Liu FT, Borel Y, Neeser JR. An intestinal galactose-specific lectin mediates the binding of murine $\mathrm{IgE}$ to mouse intestinal epithelial cells. Eur J Biochem. 1992; 203: 393-399.

Brazowski E, Dotan I, Tulchinsky H, Filip I, Eisenthal A. Galectin-3 expression in pouchitis in patients with ulcerative colitis who underwent ileal pouch-anal anastomosis (IPAA). Pathol Res Pract. 2009; 205: 551558.

Camby I, Le Mercier M, Lefranc F, Kiss R. Galectin-1: a small protein with major functions. Glycobiology. 2006; 16(11): 137R-157R.

Carey HV, Mangino MJ, Southard JH. Changes in gut function during hibernation: implications for bowel transplantation and surgery. Gut. 2001; 49(4): 459-461.

Case D, Irwin D, Ivester C, Harral J, Morris K, Imamura M, Roedersheimer M, Patterson A, Carr M, Hagen M, Saavedra M, Crossno J Jr, Young KA, Dempsey EC, Poirier F, West J, Majka S. Mice deficient in galectin-1 exhibit attenuated physiological responses to chronic hypoxia-induced pulmonary hypertension. Am J Physiol Lung Cell Mol Physiol. 2007; 292(1): L154-164.

Catt JW, Harrison FL, Carleton JS. Distribution of an endogenous beta-galactoside-specific lectin during foetal and neonatal rabbit development. J Cell Sci. 1987; 87: 623-633.

Cebo C, Vergoten G, Zanetta JP. Lectin activities of cytokines: functions and putative carbohydrate-recognition domains. Biochim Biophys Acta. 2002; 1572(2-3): 422-434

Cooper DN, Barondes SH. Evidence for export of a muscle lectin from cytosol to extracellular matrix and for a novel secretory mechanism. J Cell Biol. 1990; 110: 1681-1691.

Curciarello R, Steele A, Cooper D, MacDonald TT, Kruidenier L, Kudo T. The role of Galectin-1 and Galectin-3 in the mucosal immune response to Citrobacter rodentium infection. PLoS One. 2014; 9(9): e107933.

Delacour D, Cramm-Behrens CI, Drobecq H, Le Bivic A, Naim HY, Jacob R. Requirement for galectin-3 in apical protein sorting. Curr Biol. 2006; 16(4): 408-414.

Delacour D, Koch A, Ackermann W, Eude-Le Parco I, Elsässer HP, Poirier F, Jacob R. Loss of galectin-3 impairs membrane polarisation of mouse enterocytes in vivo. J Cell Sci. 2008; 121: 458-465.

Demetter P, Nagy N, Martin B, Mathieu A, Dumont P, Decaestecker C, Salmon IJ. The galectin family and digestive disease. Pathol. 2008; 215(1): 1-12.

Goletz S, Hanisch FG, Karsten U. Novel alphaGalNAc containing glycans on cytokeratins are recognized invitro by galectins with type II carbohydrate recognition domains. J Cell Sci. 1997; 110: 1585-1596.

Gordon-Alonso M, Bruger AM, Bruggen P. Extracellular galectins as controllers of cytokines in hematological cancer. Blood. 2018; 132(5): 484-491.

Green C. Mammalian hibernation: lessons for organ preparation? Cryo Letters. 2000; 21(2): 91-98.

Hokama A, Mizoguchi E, Mizoguchi A. Roles of galectins in inflammatory bowel disease. World J Gastroenterol. 2008; 14: 5133-5137.
Houzelstein D, Gonçalves IR, Fadden AJ, Sidhu SS, Cooper DN, Drickamer K, Leffler H, Poirier F. Phylogenetic analysis of the vertebrate galectin family. Mol Biol Evol. 2004; 21(7): 1177-1187.

Huflejt ME, Jordan ET, Gitt MA, Barondes SH, Leffler H. Strikingly different localization of galectin-3 and galectin4 in human colon adenocarcinoma T84 cells. Galectin-4 is localized at sites of cell adhesion. J Biol Chem. 1997; 272: 14294-14303

Joubert R, Caron M, Avellana-Adalid V, Mornet D, Bladier D. Human brain lectin: a soluble lectin that binds actin. J Neurochem. 1992; 58(1): 200-203.

Kaltner H, Seyrek K, Heck A, Sinowatz F, Gabius HJ. Galectin-1 and galectin-3 in fetal development of bovine respiratory and digestive tracts. Comparison of cell typespecific expression profiles and subcellular localization. Cell Tissue Res. 2002; 307(1): 35-46.

Kurtz CC, Carey HV. Seasonal changes in the intestinal immune system of hibernating ground squirrels. Dev Comp Immunol. 2007; 31: 415-428.

Lindstedt R, Apodaca G, Barondes SH, Mostov KE, Leffler H. Apical secretion of a cytosolic protein by MadinDarby canine kidney cells. Evidence for polarized release of an endogenous lectin by a nonclassical secretory pathway. J Biol Chem. 1993; 268(16): 11750-11757.

Liu FT, Patterson RJ, Wang JL. Intracellular functions of galectins. Biochim Biophys Acta 2002; 1572: 263-273.

Lotz MM, Andrews CW Jr, Korzelius CA, Lee EC, Steele GD Jr, Clarke A, Mercurio AM. Decreased expression of Mac-2 (carbohydrate binding protein 35) and loss of its nuclear localization are associated with the neoplastic progression of colon carcinoma. Proc Natl Acad Sci U S A. 1993; 90: 3466-3470.

Mizoguchi E, Mizoguchi A. Is the sugar always sweet in intestinal inflammation? Immunol Res. 2007; 37: 47-60.

Moiseeva EP, Javed Q, Spring EL, de Bono DP. Galectin 1 is involved in vascular smooth muscle cell proliferation. Cardiovasc Res. 2000; 45(2): 493-502.

Moiseeva EP, Spring EL, Baron JH, de Bono DP. Galectin 1 modulates attachment, spreading and migration of cultured vascular smooth muscle cells via interactions with cellular receptors and components of extracellular matrix. J Vasc Res. 1999; 36(1): 47-58.

Müller S, Schaffer T, Flogerzi B, Fleetwood A, Weimann R, Schoepfer AM, Seibold F. Galectin-3 modulates T cell activity and is reduced in the inflamed intestinal epithelium in IBD. Inflamm Bowel Dis. 2006; 12(7): 588597.

Nio J, Kon Y, Iwanaga T. Differential cellular expression of galectin family mRNAs in the epithelial cells of the mouse digestive tract. J Histochem Cytochem. 2005; 53(11): 1323-1334.

Nio-Kobayashi, J. Tissue-and cell-specific localization of galectins, $\beta$-galactose-binding animal lectins, and their potential functions in health and disease. Anat Sci Int. 2017; 92(1): 25-36.

Ose R, Oharaa O, Nagase T. Galectin-1 and Galectin-3 mediate protocadherin-24-dependent membrane localization of $\beta$-catenin in colon cancer cell line HCT116. Curr Chem Genomics. 2012; 6: 18-26.

Olson ME, McCabe K. Anesthesia in the Richardson's ground squirrel: comparison of ketamine, ketamine and xylazine, droperidol and fentanyl, and sodium pentobarbital. J Am Vet Med Assoc. 1986; 189: 1035-1037. 
Ozaki K, Inoue K, Sato H, Iida A, Ohnishi Y, Sekine A, Sato H, Odashiro K, Nobuyoshi M, Hori M, Nakamura Y, Tanaka T. Functional variation in LGALS2 confers risk of myocardial infarction and regulates lymphotoxinalpha secretion in vitro. Nature. 2004; 429: 72-75.

Özbek M, Hitit M, Yıldırım N, Özgenç Ö, Ergün E, Ergün L, Beyaz F, Kurtdede N, Altunay H. Expression pattern of galectin-1 and galectin-3 in rat testes and epididymis during postnatal development. Acta Histochem. 2018; 120(8): 814-827.

Öztop M, Özbek M, Liman N, Beyaz F, Ergün E, Ergün L. Localization profiles of natriuretic peptides in hearts of pre-hibernating and hibernating Anatolian ground squirrels (Spermophilus xanthoprymnus). Vet Res Commun. 2019; 43(2): 45-65.

Puthenedam M, Wu F, Shetye A, Michaels A, Rhee KJ, Kwon JH. Matrilysin-1 (MMP7) cleaves galectin-3 and inhibits wound healing in intestinal epithelial cells. Inflamm Bowel Dis. 2011; 17(1): 260-267.

Rubinstein N, Ilarregui JM, Toscano MA, Rabinovich GA. The role of galectins in the initiation, amplification and resolution of the inflammatory response. Tissue Antigens. 2004; 64(1): 1-12.

Sanjuán X, Fernández PL, Castells A, Castronovo V, van den Brule F, Liu FT, Cardesa A, Campo E. Differential expression of galectin 3 and galectin 1 in colorectal cancer progression. Gastroenterology. 1997; 113(6): 1906-1915.

Santucci L, Fiorucci S, Rubinstein N, Mencarelli A, Palazzetti B, Federici B, Rabinovich GA, Morelli A. Galectin-1 suppresses experimental colitis in mice. Gastroenterology. 2003; 124: 1381-1394.

Sisa C, Turroni S, Amici R, Brigidi P, Candela M, Cerri M. Potential role of the gut microbiota in synthetic torpor and therapeutic hypothermia. World J Gastroenterol. 2017; 23(3): 406-413.

Takenaka $Y$, Inohara $H$, Yoshii T, Oshima K, Nakahara S, Akahani S, Honjo Y, Yamamoto Y, Raz A, Kubo T. Malignant transformation of thyroid follicular cells by galectin -3. Cancer Lett. 2003; 195(1): 111-119.

Wang J, Thio SS, Yang SS, Yu D, Yu CY, Wong YP, Liao P, Li S, Soong TW. Splice variant specific modulation of CaV1.2 calcium channel by galectin-1 regulates arterial constriction. Circ Res. 2011; 109(11): 1250-1258.

Wasano K, Hirakawa Y, Yamamoto T. Immunohistochemical localization of $14 \mathrm{kDa}$ beta-galactoside-binding lectin in various organs of rat. Cell Tissue Res. 1990; 259(1): 4349.

Woo HJ, Joo HG, Song SW, Sohn YS, Chae C. Immunohistochemical detection of galectin-3 in canine gastric carcinomas. J Comp Pathol. 2001; 124(2-3): 216218.

Yang RY, Hsu DK, Liu FT. Expression of galectin-3 modulates T-cell growth and apoptosis. Proc Natl Acad Sci U S A. 1996; 93(13): 6737-6742. 